\title{
MEMÓRIA E IMAGEM NAS OBRAS DE JULIANA CRISPE
}

\section{MEMORY AND IMAGE IN THE WORKS OF JULIANA CRISPE}

Francine Regis Goudel ${ }^{1}$ 


\section{Resumo}

O presente artigo apresenta o processo de criação da artista visual Juliana Crispe (Florianópolis, 1982). As proposições de Juliana apontam direções a serem pensadas com principal base no conceito de memória, e em como as lembranças de sua vida possibilitam o subsidio criador de seus objetos artísticos. $O$ texto apresenta um caráter biográfico, da relação vivida entre autora e artista, e por vezes insinua um tom pessoalizado e afetivo. A maneira de escrita adotada é proposital, pois apresenta um dos fatores disparadores para entrada da obra de Juliana: torna-se parte constitutiva do processo artístico. O fio condutor do artigo é a história de Ireneo Funes, personagem criado por Borges, figura adequada para tecer as analogias e convergências de duas fabulações de memória. Algumas postulações de autores como Henri Bergson, Jacques Derrida e Didi-Huberman, possibilitam ampliar os conceitos abordados e entrar no mundo de ressignificação da artista, oportunizando uma reflexão sobre como as obras surgem e passam a transmitir, de forma poética, toda sua heterogeneidade e anacronismo.

Palavras-chave: Juliana Crispe, Memória, Arquivo, Conhecimento por montagem, Imagem Real.

\section{Abstract}

This article presents the process of creation of visual artist Juliana Crispe (Florianópolis, 1982). The propositions of Juliana point out directions to be thought with main basis in the concept of memory, and in how the memories of its life make possible the creative subsidy of its artistic objects. The text presents a biographical character, of the relationship lived between author and artist, and sometimes insinuates a personal and affective tone. The way of writing adopted is purposeful, since it presents one of the triggers for Juliana's work: it becomes a constitutive part of the artistic process. The thread of the article is the story of Irenaeus Funes, a character created by Borges, a figure suitable for weaving the analogies and convergences of two memory fables. Some postulates by authors such as Henri Bergson, Jacques Derrida and Didi-Huberman, make it possible to broaden the concepts approached and enter the world of the artist's resignification, giving a reflection on how the works emerge and begin to transmit, in a poetic way, all their heterogeneity and anachronism.

Keywords: Juliana Crispe, Memory, Archive, Knowledge by montage, Real Image.

ISSN: 2175-2346

1 francinegoudel@gmail.com 


\section{Introdução: Entrando nas fabulações}

Ireneo Funes, a personagem criada por Jorge Luís Borges (1899-1986), carrega consigo a corpulenta sina de não esquecer de nada do que vive (BORGES, 2007). Funes - o memorioso, como apresenta o autor, personifica nas páginas literárias a angustiante ideia de como seria uma vida sem esquecer de nada, como seria se a memória fosse completamente límpida e ativa, sem lapsos, recalques ou sublimações.

Se para Henri Bergson (1859-1941), "não há e nem pode haver no cérebro uma região onde as lembranças se fixem ou acumulem" (1999, p. 146), Funes, para o filósofo, seria o alto grau da ficção ou a personificação de um grande mistério. Para o filósofo a memória se dá de forma fragmentada, e é estabelecida, acima de tudo, pelo presente incitado. A lembrança então, para o autor, se dá através de ações corpóreas vigentes no atual momento, onde somente um corpo-presente-em-deslocamento dá subsidio a memória:

Para que uma lembrança reapareça à consciência, é preciso com efeito que ela desça das alturas da memória pura até o ponto preciso onde se realiza a ação. Em outras palavras, é do presente que parte o apelo ao qual a lembrança responde, e é dos elementos sensório-motores da ação presente que a lembrança retira o calor que lhe confere vida. (BERGSON, 1999, p. 179)

Essa relação divergente entre a história de Funes e a proposição de Bergson, ou seja, acumulo e impossibilidade de acumulo de memória, seria maneira oportuna de entrada no trabalho da artista Juliana Crispe. A materialização de suas obras parte de um movimento produtivo que parece simples: a ressignificação da memória no presente. Conferir vida as lembranças de infância é questão perene nos trabalhos da artista. Materialização e ressignificação da memória no presente através de objetos artísticos é o feixe produtivo da jovem artista Florianopolitana, que em suas próprias palavras ganha tom palpável e maciço: "estou interessada em explorar criativamente como as minhas experiências podem tornar-se substratos para obras a serem realizadas, ou seja, como traduzir a experiência vivida em trabalho artístico" (PEREIRA, 2011, p.31-32). Nessa apreensão, Crispe transforma a própria biografia em matéria, ora expondo o mais íntimo arquivo transformado em poética, ora configurando sua vivência em uma completa fabulação.

Talvez fosse pertinente apresentar brevemente Juliana, antes de entrarmos propriamente em seu mundo. Juliana Crispe é artista visual, arte-educadora, curadora e propositora de diversos projetos artístico-culturais. Graduada em Licenciatura e Bacharelado em Artes Visuais pela Universidade do Estado de Santa Catarina, fez seu mestrado na mesma instituição na linha de Processos Artísticos, realizando uma monografia que desenvolveu em base na reflexão sobre seu próprio trabalho artístico. Já seu doutorado, realizado na área de Educação na Universidade Federal de Santa Catarina, desenvolveu a tese "Cartografias afetivas", que teve como objetivo mapear os territórios afetivos de diversos convidados participantes. Atuou como professora colaboradora no curso de Artes Visuais na UDESC nos anos de 2011 a 2015, e atualmente a partir do ano de 2017. Fomentadora da cena artística regional, é idealizadora do 
Projeto Armazém ${ }^{1}$, um projeto colaborativo fundado em 2011, do qual deriva dele em 2016 o Espaço Cultural Armazém - Coletivo Elza, um espaço/coletivo de mulheres artistas, localizado no bairro Sambaqui, em Florianópolis, onde vive e trabalha.

Como Ireneo Funes, que era "natural de Fray Bentos, com certas limitações incuráveis" (BORGES, 2007, p.104), Juliana Crispe apresenta afinidades com a personagem do Rio Negro: nascer em uma capital provinciana e da memória de sua infância não esquecer, inspirando seu processo artístico como Louise Bourgeois o fez e também declarou ser sua potência. (BOURGEOIS, 2000)

Poderia aqui parafrasear Borges, quando descreve como o narrador do conto lembra como conheceu Funes pela primeira vez, escrevendo que "a minha primeira lembrança de [Juliana] é muito clara"2. E como autora deste artigo eu poderia ir além, mencionando que esta lembrança não remonta qualquer parede branca de galerias de arte ou encontro badalado nos eventos culturais da capital provinciana, mas que, igualmente como no conto portenho, a lembrança irrompe da infância. Deambula na recordação do partilhar a vivência de um bairro simples, de casas empilhadas na montanha e calçadas empoçadas pela chuva que o velho vento sul tão conhecido a trazia.

Uma menina prosperada na década de 90, época das brincadeiras ao ar livre, carros sem a obrigatoriedade do cinto de segurança em seus passeios e o cuidado lúdico dos avós. Na ocasião primeira que lembro, ao contrário da história de Funes, quem estava com o primo era Juliana. O menino, mais velho, despejava toda sua puberdade delirante em uma simples brincadeira de roda onde estávamos, o que no alto de nossos sete-nove anos de idade causava confusão. Mas, Juliana não ligava. Anacrônica, tinha o sorriso enigmático de uma madona renascentista e firmeza aerada em sua expressão, cultivava um olhar de quem observa a paisagem todos os dias da janela de seu quarto no alto do morro do bairro simples, e imagina muita intensidade num grande azul de céu.

O encontro posterior com Juliana então se daria, anos mais tarde, em uma feliz coincidência: na partilha dos estudos acadêmicos e da mesma área profissional. $\mathrm{E}$ assim tomo conhecimento de seu processo artístico, com o trabalho do ano de 2007 titulado Coisas que olham para o céu (Fig.1). No mesmo em que vejo a obra remonto minha infância e a lembrança desse primeiro encontro com Juliana. A vasta visão de céu, o enquadramento-esmagamento do horizonte sem chão, prédios e antenas figurantes a distância. A perspectiva de Crispe nestas fotografias afeta o feixe de minhas lembranças, pois justamente partilhávamos de um olhar compositivo semelhante, o olhar da criança que vê desde a janela da sua casa na montanha aquele trecho intenso de céu.

\footnotetext{
1 "O projeto Armazém apresenta, através de exposições e feiras de arte, obras que sejam múltiplos [...]. O título do projeto é inspirado na primeira edição do Armazém que aconteceu no Museu Victor Meirelles, em Florianópolis-SC. O Museu foi a casa natal de Victor Meirelles e se tornou um bar e armazém durante parte da primeira metade do século 20. [...] A imagem utilizada para compor os cartazes de todas as edições é uma fotografia de acervo familiar da idealizadora do projeto, Juliana Crispe. Um retrato do seu bisavô, Osvaldo Manoel Valgas, conhecido como seu Vadico, que entre as décadas de 1930 e 1990 foi sócio/funcionário de um armazém, no bairro Prainha, próximo ao centro da cidade de Florianópolis." Disponível em: <https://www.facebook.com/armazem.feira.exposicao. publicacoesdeartista/> Acesso 31 de janeiro de 2017

2 Sobre como o autor lembra do Funes pela primeira vez: "A minha primeira lembrança de Funes é muito clara. Vejo-o em um entardecer de Março ou Fevereiro do ano de 1884. Meu pai, nesse ano, levara-me a veranear em Fray Bentos. Voltava com meu primo Bernardo Haedo da estância de San Francisco. Voltávamos cantando, a cavalo, e essa não era a única circunstância da minha felicidade" (BORGES, 2007, p.104).
} 

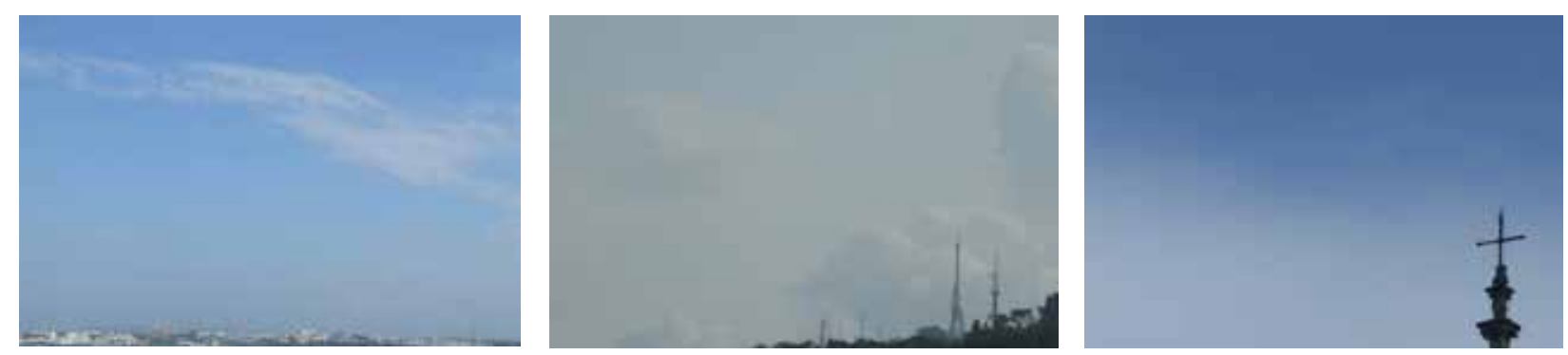

Fig. 1 - Coisas que olham para o céu. Juliana Crispe, 2007.Fotografia Juliana Crispe. Fonte: acervo particular.

\section{Memória como princípio ativo}

Entre infância, adolescência e a vida adulta, houve o momento do "acidente de Funes" no processo criativo de Juliana Crispe. O momento do seu acidente, do exato momento que definiria o rumo de sua perspectiva, do qual tornaria a memória afetiva o combustivel para uma criação, não saberia explicitar jamais. Porém, partilhei da primeira proposta concreta do trabalho da artista ao ver Coisas que olham para o céu:

muitas vezes o espectador passa a ser um perceptor e colaborador nos processos de cada trabalho, suas ações tornam-se um retorno inesperado que particularmente me motiva para o ato criativo. Ao falar de memória, lembranças e afetos, busco construir uma obra que possa ser entendida como elemento propulsor de relações, envolvendo o espectador, tratando-o como elemento constitutivo do processo. [...] minha criação poética torna-se propósito para intervir nos espaços de vivência, criando relações de trocas de lembranças, nas quais se possa, subjetivamente, tanto cativar imageticamente o outro, quanto exercer um contraponto crítico-reflexivo sobre os acontecimentos da vida. (PEREIRA, 2012, p. 33-34)

Porém, ao contrário de Funes, descrito no conto como o Homem "verdadeira enciclopédia", aquele que lembrava de inúmeros dados e textos, mas não sabia "elaborar estes conhecimentos" (BORGES, 2007, p. 105), Crispe, ao contrário, elabora sua memória de forma sensível. Concebe uma engenhosa dança entre lembrança, percepção e visualidade, para criar uma sutil atmosfera de envolvimento com o espectador.

Na obra Desejo que seus desejos se realizem (Fig.2), de 2008, Crispe coletou durante aproximadamente dois anos os cílios que caiam de seu próprio rosto. Da lembrança da brincadeira de infância, onde se apertava entre polegares o cílio desgarrado para se fazer um pedido, a artista construiu 100 pequenos pingentes para guardar os cílios colecionados e destes 95 foram doados pela artista para amigos, parentes e pessoas desconhecidas. Como na memória remontada da brincadeira, os polegares que se desgrudam mostram quem terá o pedido atendido, e será a mesma pessoa que irá guardar o cílio no peito. A criação do pingente é então uma alusão a esta ação. Já o nome da obra vem de uma inclinação primeira muito mais íntima da lembrança da artista: "Minha avó me ensinou que no terceiro pedido deveríamos mentalmente desejar para o outro 'desejo que seus desejos se realizem'. Foi dessa lembrança que surgiu o trabalho." (PEREIRA, 2012, p. 124). 


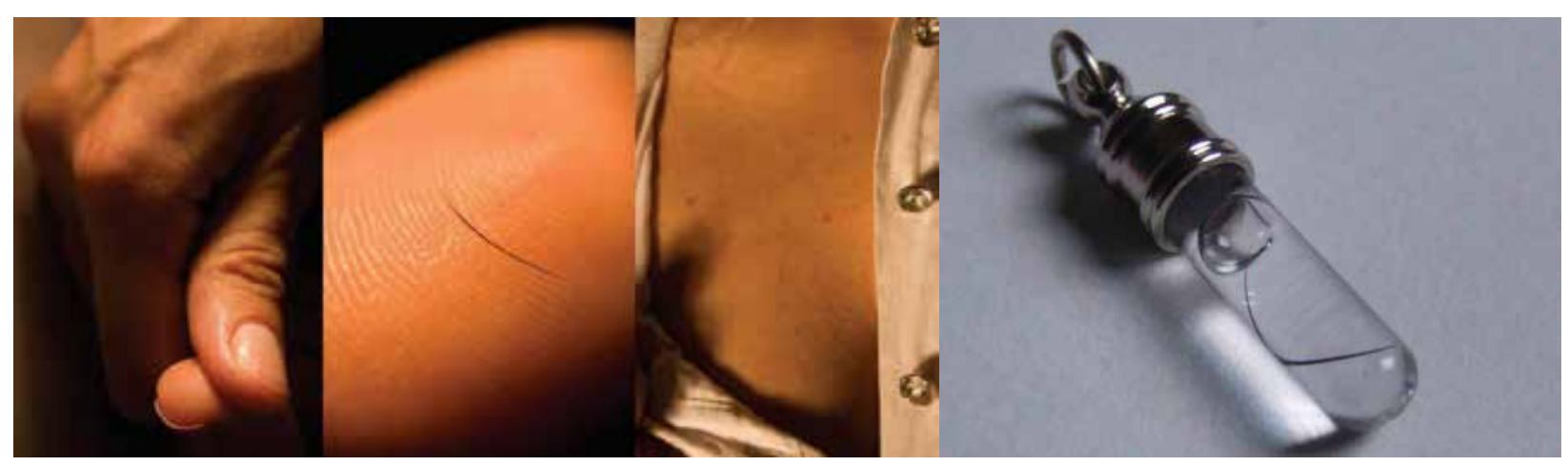

Fig. 2 - Desejo que seus desejos se realizem. Juliana Crispe, 2008. Fotografia Juliana Crispe. Fonte: acervo particular.

A memória da infância com a avó paterna parece ser a motriz propulsora de muitos trabalhos de Juliana Crispe. Como em Funes, onde as "lembranças não eram simples; cada imagem visual estava ligada a sensações musculares, térmicas, etc" (BORGES, 2007, p. 105), a artista evidencia em seu trabalho a reconstrução dos "entressonhos" com a avó, e elucida seu processo de criação em forma de texto, na lembrança de criação da obra A mulher que derreteu (Fig.3), de 2010:

O desejo de construir esse trabalho está por trás de um fato acontecido no ano de 1996, durante a missa de sétimo dia da morte de minha avó Lia. Ao estar sentada na igreja, compenetrada na missa, transpirei pelas mãos mais do que normalmente transpirava, originando uma poça de suor no chão. Esse fato chamou a atenção de meus familiares, e essa cena ficou marcada em minha memória, não apenas pela atenção despertada, mas também pela emoção daquele momento, provavelmente, fator desencadeador desse processo. Assim, a mulher que derreteu, leva-me diretamente a lembrança de um passado e a relação com a perda física de uma pessoa importante em minha vida. (PEREIRA, 2012, p. 130)

Em seu texto descreve, anos mais tarde, a evidencia do processo de construção da obra. A cena marcada na sua memória, gerada pela atenção de todos os familiares e também pela emoção do momento, certamente foi o fator desencadeador do trabalho. Neste trabalho, Crispe reconstrói poeticamente a cena, através de uma vídeo projeção. A própria mão centralizada na imagem, transpira o suor que goteja lentamente em um pequeno pote de vidro. A instalação da obra se dá então com uma tela onde mostra a cena capturada e ao lado o pequeno pote, já abastecido com o derretimento de seu corpo. 


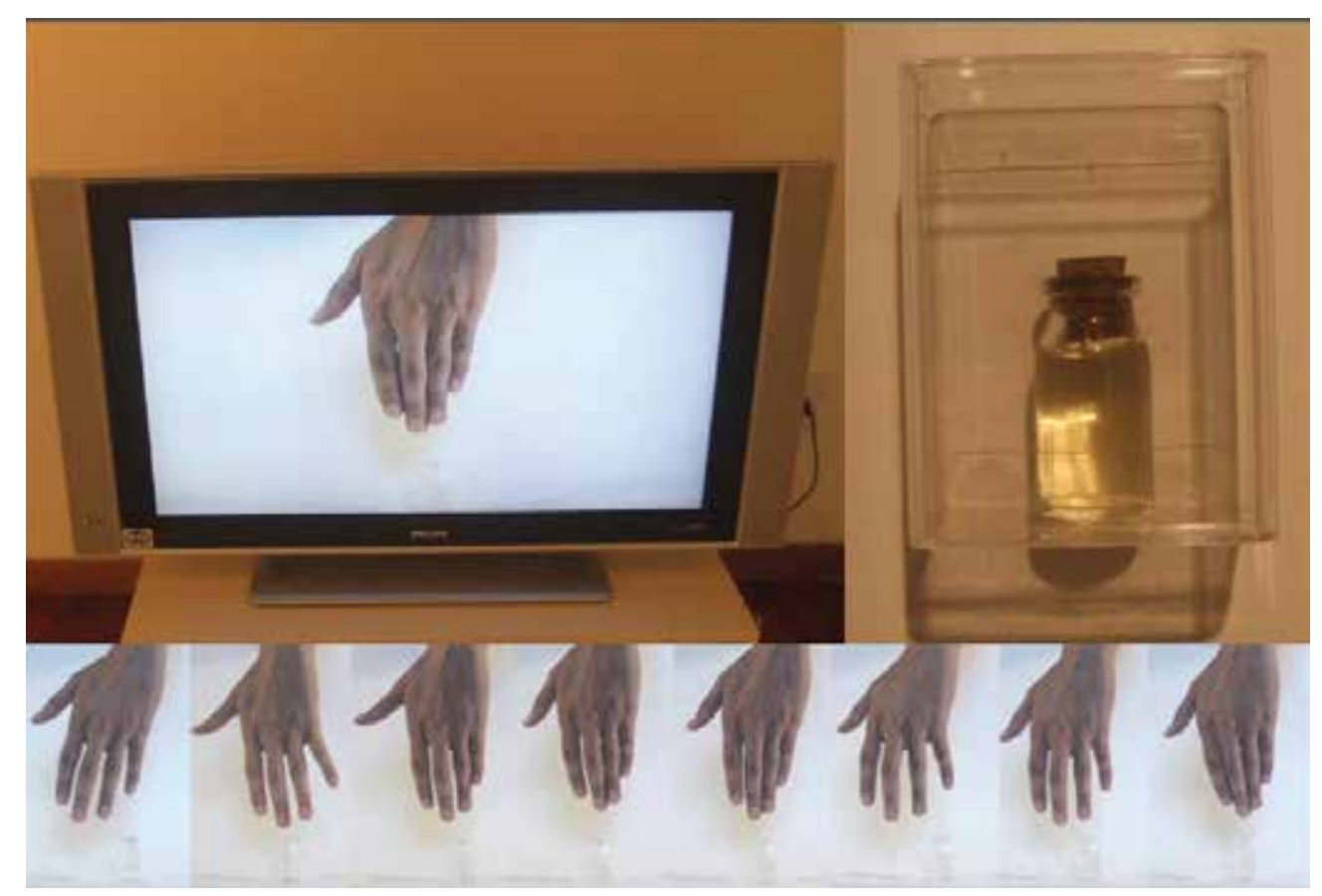

Fig. 3 - A mulher que derreteu. Juliana Crispe, 2010. Fotografia Juliana Crispe. Fonte: acervo particular.

Na obra Liaessência, de 2007 (Fig.4), a lembrança da avó permeia e ilustra a construção do trabalho. O material utilizado em seus objetos-instalações, como os vidros coletores que suportam as duas obras mencionadas, Desejo que seus desejos se realizem (Fig.2), de 2008 e A mulher que derreteu (Fig.3), de 2010, parecem também ganhar destaque na análise dos trabalhos de Crispe. Os suportes remetem ao seu próprio tema, recipientes receptores de memória que conseguem capturar a lembrança e ainda assim manter o distanciamento necessário do espectador. Em outras obras da artista encontramos também esses objetos de guardar pequenas coisas, pingentes, potes, caixinhas de madeira, onde ela coloca seus insights, presentificando uma lembrança, mas ainda assim resguardando sua memória na exibição (Fig.5-6).

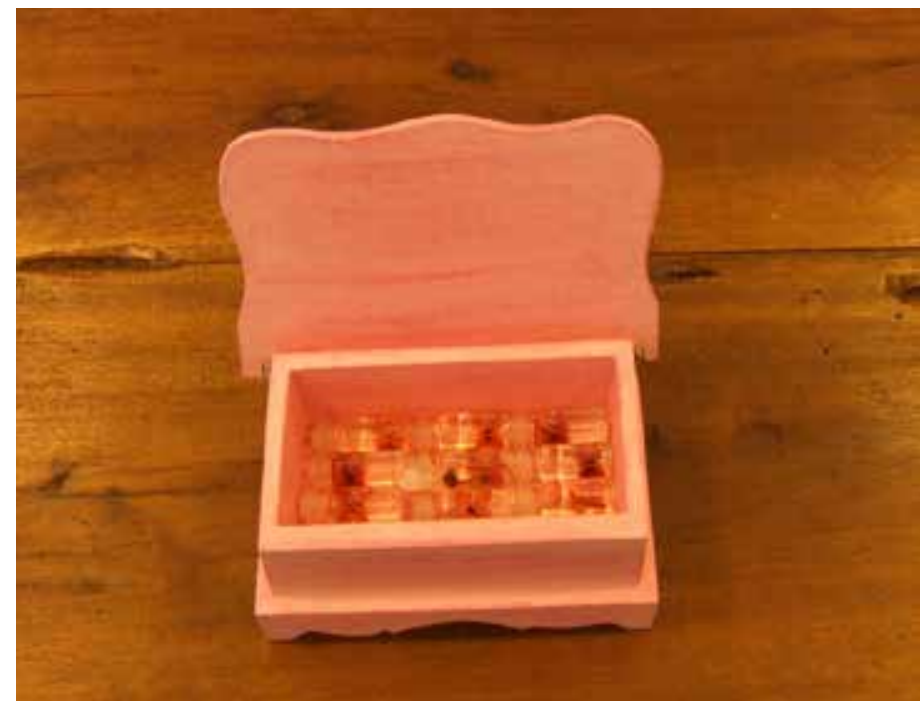

Fig. 4 - Liaessência. Juliana Crispe, 2007. Fotografia Juliana Crispe. Fonte: acervo particular. 


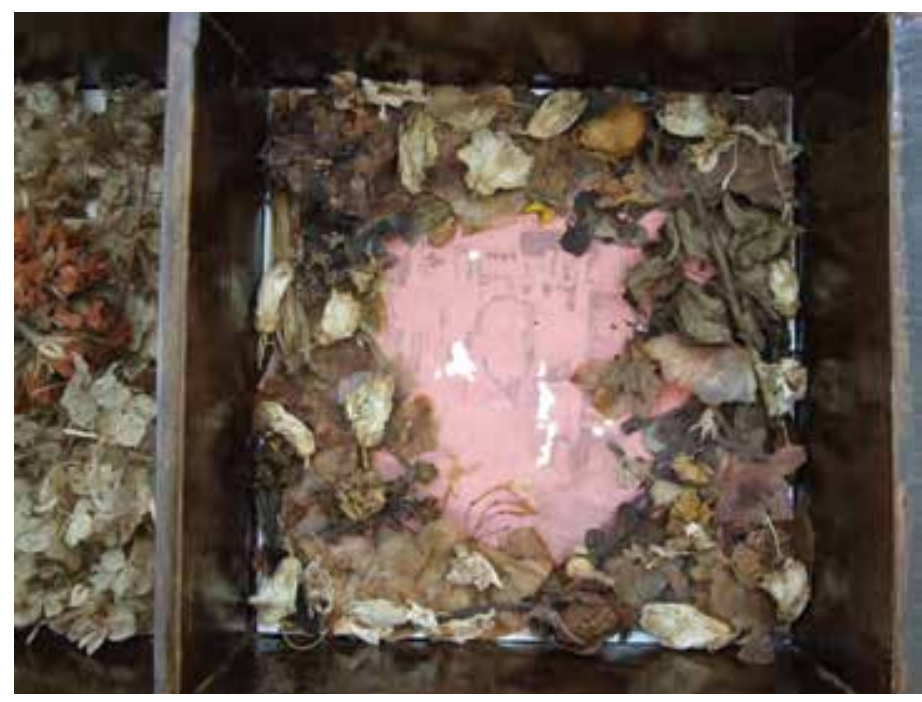

Fig. 5 - Sem título (bisavô). Juliana Crispe, 2007. Fotografia Juliana Crispe. Fonte: acervo particular.

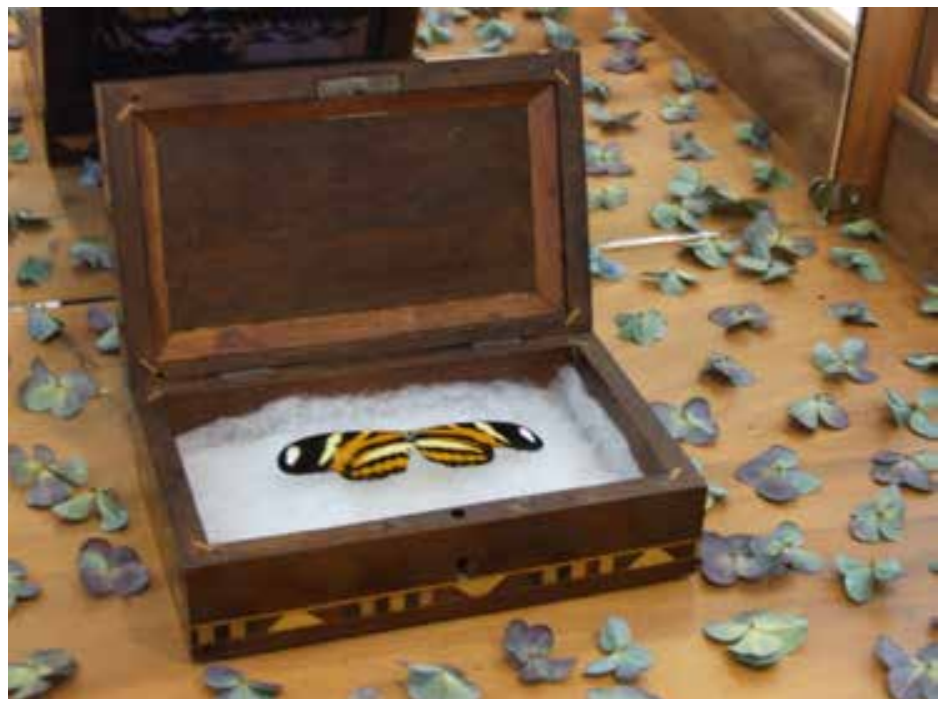

Fig. 6 - Borboletas viram fadas?. Juliana Crispe, 2007. Fotografia Juliana Crispe. Fonte: acervo particular.

Seriam esses recipientes, para a artista, de alguma forma o suporte de um processo de retenção, de um local de acervo dessa memória? Seria, para ela, uma maneira matérica de compartilhar um arquivo, ressignificado por imagens e objetos potencializados? Um arquivo de afetos poéticos? As respostas para estas perguntas aqui neste texto serão apenas mais pistas para pensar sobre o processo da artista.

\section{0 desejo da materialidade}

Para o filósofo, Jacques Derrida (1930-2004), a palavra arquivo seria em sua força inicial o local de morada, a residência de um poder, o poder primitivo, onde tudo começa (DERRIDA, 2001). Entrar ou pensar sobre um arquivo pessoal, para o autor, seria entrar em uma memória que ascende rastros de questões afetivas, vivenciadas, estabelecidas, reais e ficcionais: o poder memorável de cada indivíduo. Em seu livro Mal de Arquivo: uma impressão freudiana (DERRIDA, 2001), Derrida trata de analisar 
o arquivo, e toda sua potência escrita, através de duas grandes frentes psicanalíticas: desejo e morte. $\mathrm{O}$ "mal do arquivo" seria, em certa medida, o desejo de memória, o "arder dessa paixão", mas também a pura "pulsão de morte", a mesma que tem por objetivo extinguir o memorável:

A perturbação do arquivo deriva de um mal de arquivo. Estamos com mal de arquivo [...] pode significar outra coisa que não sofrer de um mal, de uma perturbação ou disso que o nome 'mal' poderia nomear. É arder de paixão. É não ter sossego, é incessantemente, inevitavelmente procurar o arquivo onde ele se esconde. [...] um desejo irreprimível de retorno a origem, uma dor pátria, uma saudade de casa, uma nostalgia do retorno ao lugar mais arcaico do começo absoluto. Nenhum desejo, nenhuma paixão, nenhuma pulsão, nenhuma compulsão, nem compulsão de repetição, nenhum' mal-de', nenhuma febre, surgirá para aquele que, de um modo ou outro, não está já com mal de arquivo. (DERRIDA, 2001, p. 118-119)

Neste sentido poderíamos então dizer que Juliana Crispe sofre deste "mal", e o processo de arquivamento de suas lembranças urge, no desejo ou na pulsão, por uma materialidade singular. Na obra (i)mobilidade do olhar, (Fig.7) dos anos de 2005-2017, a artista parece entrelaçar os conceitos desse arquivo elucidado por Derrida. Através do próprio antigo arquivo fotográfico familiar, a artista ressignifica a lembrança dos entes, num misto entre memória, morte e desejo, em um vídeo de 9 minutos. Explana a artista sobre esta criação:

Apropriando-me desses álbuns de família, pude traçar uma passagem de alguém levado pela morte. As sequências de imagens no vídeo assemelham-se a imagens de ultrassonografia, mas ao invés de dar visibilidade a um feto em desenvolvimento, revela imagens associadas à morte, um misterioso destino comum a todos, evocando uma espécie de visão interior e subjetiva, que acrescenta e suprime informações, que reconstrói e recria a memória. Trata-se não da morte propriamente dita, mas sim da lembrança infantil, que resgata na memória certos momentos que foram perdidos no tempo, transformando-os ao relembrá-los. (PEREIRA, 2012, p. 68)

O vídeo é feito com base nas fotografias de seu acervo pessoal, posicionando uma espécie de pedra translúcida para criar as imagens. Ora essa pedra se torna imagem densa e cobre a fotografia, ora desvela a imagem e revela de forma fantasmagórica uma cena afetiva de um tempo remoto. As imagens apresentadas se assemelham a imagens de ultrassonografia, contudo o feto não é desvelado, o que vemos são as personagens de um passado. O som do vídeo, memorioso e em parte fúnebre, nos leva a configurar a obra para além da imagem de estranheza desse "ultrassom" póstumo. Permeia a sensação de um desejo fecundo de retorno e não esquecimento. 

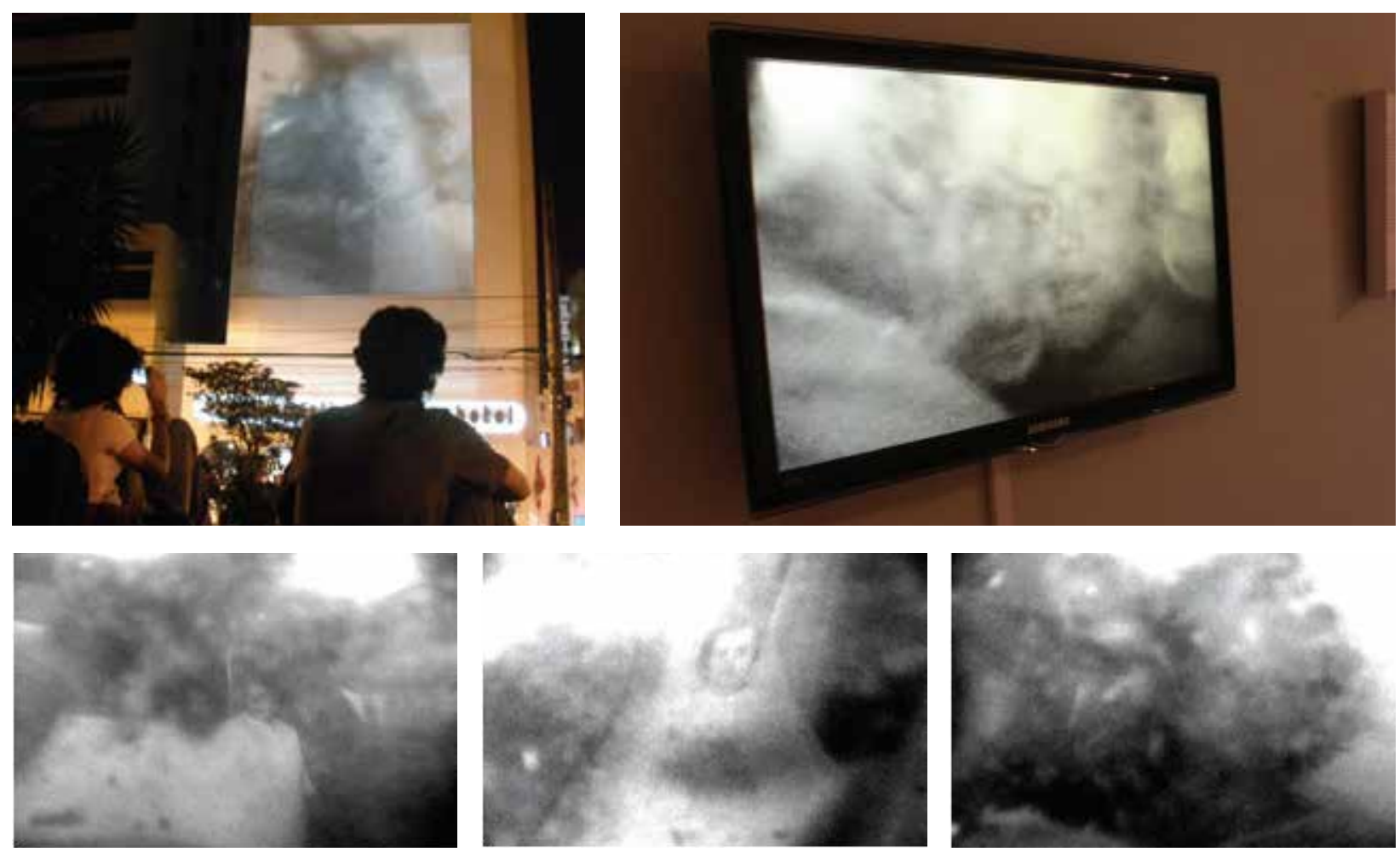

Fig. 7 - (i)mobilidade do olhar. Juliana Crispe, 2005-2010. Fotografia Juliana Crispe, acervo particular. Projeção de intervenção urbana chamada Deriva (2010) na Fundação Cultural BADESC e instalação dentro do espaço expositivo. Abaixo stills de vídeo.

Parece haver nos trabalhos de Crispe uma grande gama de conceitos a serem pensando que não dizem respeito somente a relação da memória. A memória seria ao certo o feixe disparador de seu trabalho, porém a montagem de um segundo arquivo através do objeto artístico, a partir de seu arquivo de infância, pode nos levar aos conceitos do historiador Georges Didi-Huberman (1953-), e suas postulações sobre um "conhecimento por montagem", "sintoma" e "imagem real".

O infinito e incessante enigma da História da Arte, o montar a memória para ser visual, construir o "entressonho" de Funes, é para o autor uma montagem de imagens de base anacrônica:

\footnotetext{
No se puede hacer una verdadera historia de las imágenes siguiendo simplemente el modo de la crónica lineal, de la crónica cronológica, por la simple razón de que una sola imagen - al igual que un solo gesto -, reúne en sí misma varios tiempos heterogéneos. [...] la fotografía sería el lugar donde se capta, bajo la forma de un fantasma, la verdad del ser - y una retórica. [...] por eso el «síntoma» es tan importante para mí, porque es un concepto semiótico -habla del significado-, pero es también corporal. Y esto es precisamente lo que es un gesto: un movimiento del cuerpo que está investido de cierta capacidad de significado o de expresión. Por lo tanto, lo que nos interesa es, en realidad, lo que ocurre entre el mundo de los signos y el mundo del cuerpo. (DIDI-HUBERMAM apud ROMERO, 2007, p. 19)
}

Assim como Bergson, que entende a importância do gesto postulante na ação da memória, Didi-Huberman estabelece um conceito pertinente para pensar o que na imagem produzida, no gesto incitado do presente, reverbera um mundo de imagens de tempos passados. 


\section{Considerações finais: $O$ retorno das imagens}

O conceito trabalhado por Didi-Huberman, postulado como "sintoma" ou "trecho", nada tem a ver com questões entre significantes das imagens propostas, que acenam um contexto ou história verídica. Deve ser lida através de um viés de como a apresentação destas imagens se dão como criação, como ela é entendida como imagem que carrega consigo outros tempos e lembranças, como se dá no olhar do espectador por vez primeira, e como ela própria destaca seus pontos importantes em seu todo (DIDI-HUBERMAM, 2013). É onde a imagem irá "arder", onde "uma das grandes forças da imagem é criar ao mesmo tempo sintoma (interrupção no saber) e conhecimento (interrupção no caos)" (DIDI-HUBERMAM, 2012, p. 214). Mas a imagem não se apresenta por completo de forma imediata:

As noções de memória, montagem e dialética estão aí para indicar que as imagens
não são nem imediatas, nem fáceis de entender. Por outro lado, nem sequer estão
"no presente", como em geral se crê de forma espontânea. E é justamente por que
as imagens não estão "no presente" que são capazes de tornar visíveis as relações
de tempo mais complexas que incumbem a memória na história. (DIDI-HUBER-
MAM, 2012, p. 213)

Na obra de Juliana Crispe titulada Espera (Fig.8), de 2010, o sintoma e a montagem, se apresentam através do gesto que recria a fabulação de uma história. Novamente impulsionada por uma lembrança da avó, Crispe representa através de imagens a história contada por Lia: que as borboletas viram fadas quando morrem. Na criação da obra "não houve de fato borboletas capturadas, as que aparecem nas imagens são borboletas colecionadas [...] e estas se encontram em processo de decomposição, faltando pedaço das asas, antenas, do corpo, possível de ser notado" (PEREIRA, 2012, p. 145).

A fabulação de uma lembrança nesta obra é o gesto anacrônico que transforma a visualidade das borboletas despedaçadas em puro acontecimento. Por certo, não se trata de dizer se o gesto foi falso ou verdadeiro (DIDI-HUBERMAM apud ROMERO, 2007), existe aqui apenas a necessidade de saber se a "imagem é real", e "imagem real" para Didi-Huberman nada tem a ver com ser fatídica ou verdadeira, quer expressar a ideia de quando a imagem toca uma esfera de realidade dentro de nós, ou seja, onde irá nos consumir, nos afetar:

Assim como não há forma sem formação, não há imagem sem imaginação. Então, por que dizer que as imagens poderiam "tocar o real"? Porque é um enorme equívoco querer fazer da imaginação uma pura e simples faculdade de desrealização. [...] Ocorre, portanto, que as imagens toquem o real. Mas, o que ocorre nesse contato? A imagem em contato com o real - uma fotografia, por exemplo - nos revela ou nos oferece unívocamente a verdade dessa realidade? Claro que não. [...] a imagem arde em seu contato com o real. Inflama-se, e nos consome por sua vez. (DIDI-HUBERMAN, 2012, p.208) 

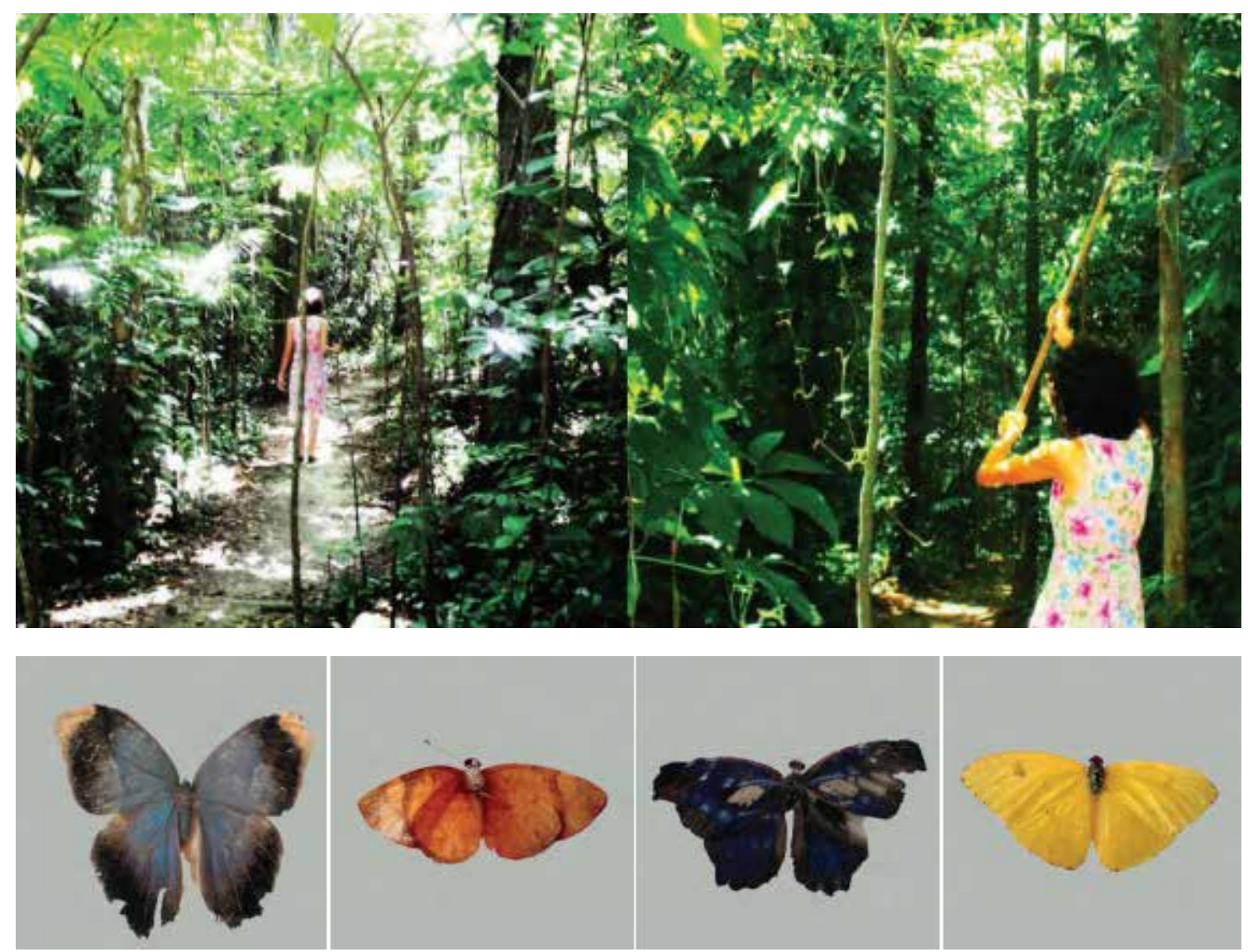

Fig. 8 - Espera. Juliana Crispe, 2010. Fotografia Juliana Crispe, acervo particular.

No texto Quando as imagens tocam o real, de 2012, Didi-Huberman trilha de forma primorosa as indagações em torno da questão do aparecimento, desaparecimento e importância da permanência e imanência da imagem. Uma imagem é capaz de reunir em sua essência complexos níveis de interlocução, "deve ser entendida ao mesmo tempo como documento e como objeto de sonho, como obra e objeto de passagem, como monumento e objeto de montagem" (DIDI-HUBERMAM, 2012, p. 209).

Diante disso, o artista poderia ser entendido como a figura crucial no desdobramento dessa interlocução. Seria ele o responsável por nos transmitir, sutilmente, de forma poética e visual, por onde as imagens podem se manifestar:

Saber olhar uma imagem seria, de certo modo, tornar-se capaz de discernir o lugar onde arde, o lugar onde sua eventual beleza reserva um espaço a um "sinal secreto", uma crise não apaziguada, um sintoma. O lugar onde a cinza não esfriou. [...] Porque a imagem é outra coisa que um simples corte praticado no mundo dos aspectos visíveis. É uma impressão, um rastro, um traço visual do tempo que quis tocar, mas também de outros tempos suplementares - fatalmente anacrônicos, heterogêneos entre eles - que não pode, como arte da memória, não pode aglutinar. É cinza mesclada de vários braseiros, mais ou menos ardentes. (DIDI-HUBERMAM, 2012, p. 215-216)

Espera (Fig. 8), por sua composição, remete a uma interessante experiência de memória e pode ser lida por uma construção metafórica feita por Didi-Huberman, sobre a potência da imagem ser como uma borboleta: 


\begin{abstract}
Hace poco he acabado un texto sobre la imagen como mariposa. Si realmente quieres verle las alas a una mariposa primero tienes que matarla y luego ponerla en una vitrina. Una vez muerta, y sólo entonces, puedes contemplarla tranquilamente. Pero si quieres conservar la vida, que al fin y al cabo es lo más interesante, sólo veras las alas fugazmente, muy poco tiempo, un abrir y cerrar de ojos. Eso es la imagen. La imagen es una mariposa. Una imagen es algo que vive y que sólo nos muestra su capacidad de verdad en un destello. (DIDI-HUBERMAM apud ROMERO, 2007, p. 19.)
\end{abstract}

Arde então na memória presente de Juliana Crispe a vontade do retorno das imagens de sua lembrança. Como em Funes, que há uma consciência particular da tarefa interminável da memória, ao contrário dele existe em Juliana a sensação de que sua produção baseada na memória de infância diz respeito a uma memória afetiva coletiva. Funes "pensou que na hora da morte não havia acabo ainda de classificar todas as lembranças da infância" (BORGES, 2007, p. 106), era um desejo dele de ordem prática, classificatória, talvez sem muita elaboração. Para Juliana o processo é reverso. As imagens que "ardem" em sua lembrança tomam forma de combustível artístico. $O$ afeto que the afeta é generosamente partilhado e ampliado até nós, os espectadores, fazendo com que nos "arda" algo também na experiência com a obra e que nos leve a outros níveis de sensibilidade e interlocução.

Talvez Crispe siga materializando as imagens que "ardem" em sua lembrança, em anacronismo, memória e imagem. Não desejamos a opulenta vida de Funes para Juliana, mas partilhando e experienciando a obra desta artista desejamos, intimamente, que a memória siga ardendo em seus próximos trabalhos.

\title{
Referências
}

BERGSON, H. Matéria e memória: ensaio sobre a relação do corpo com o espírito. Tradução de Paulo Neves. São Paulo: Martins Fontes, 1999.

BORGES, J. L. Ficções. Tradução de Davi Arrigucci Jr. São Paulo:

Companhia das Letras, 2007.

BOURGEOIS, L. Destruição do pai / Reconstrução do pai: escritos e entrevistas (1923-1997). Tradução de Álvaro Machado, Luiz Roberto Mendes Campos. São Paulo: Cosac Naify, 2000.

DERRIDA, J. Mal de Arquivo: uma impressão freudiana. Rio de Janeiro: RELUME-Dumará, 2001.

DIDI-HUBERMAN, G. A imagem sobrevivente: história da arte e tempo dos fantasmas segundo Aby Warburg. Rio de Janeiro: Contraponto, 2013.

Diante da imagem: questão colocado aos fins de uma história da arte. São Paulo: Ed. 34, 2013. 
Quando as imagens tocam o real. Tradução Patrícia Carmello e Vera Casa Nova. Revista Pós: Revista do Programa de Pós-Graduação em Artes da Escola de Belas Artes da UFMG. V. 2. N. 4. Nov. 2012. Disponível em <http:// www.eba.ufmg.br/revistapos/index.php/pos/article/view/60> Acesso em $16 \mathrm{dez}$. 2016.

PEREIRA, J. C. Entre ficção e realidade: memórias da artista-personagem. Dissertação (Mestrado) - Universidade do Estado de Santa Catarina, Centro de Artes, Mestrado em Artes Visuais, Florianópolis, 2011.

ROMERO, P. Un conocimiento por el montaje. Entrevista com Georges Didi-Huberman. Revista Minerva no5, Madrid: 2007. Disponível online em <http://www. circulobellasartes.com/revistaminerva/articulo.php?id=141>Acesso em 16 dez. 2016. 